\title{
MANAJEMEN GIZI ATLET CABANG OLAHRAGA UNGGULAN DI KABUPATEN BULELENG
}

\author{
Ni Luh Kadek Alit Arsani ${ }^{1}$, Ni Nyoman Mestri Agustini ${ }^{2}$, I Nyoman Sudarmada ${ }^{3}$ \\ 1,3 Jurusan IImu Keolahragaan, Fakultas Olahraga dan Kesehatan \\ 2Jurusan Pendidikan Jasmani Kesehatan dan Rekreasi \\ Universitas Pendidikan Ganesha \\ Singaraja, Indonesia
}

e-mail: alit_arsani@yahoo.com, mes3agustini@yahoo.com

\begin{abstract}
Abstrak
Pembinaan prestasi olahraga merupakan salah satu agenda tahunan yang menggunakan dana pemerintah cukup besar baik di tingkat nasional maupun di daerah. Salah satu aspek penting yang sering terlupakan dalam pembinaan atlet adalah faktor gizi atlet. Penelitian ini bertujuan untuk 1) mengetahui keberadaan cabang olahraga unggulan di Kabupaten Buleleng; 2) mengetahui manajemen gizi atlet cabang olahraga unggulan di Kabupaten Buleleng; 3) mengetahui kesesuaian manajemen gizi atlet cabang olahraga unggulan di Kabupaten Buleleng. Metode penelitian ini adalah deskriptif kualitatif, dengan teknik pengumpulan data melalui observasi, wawancara, dan dokumentasi. Informan dipilih secara purposive sampling. Data dianalisis dengan menggunakan Analisis Interaktive model dari Miles. Hasil penelitian diperoleh bahwa 1) Cabang olahraga yang menjadi unggulan Kabupaten Buleleng adalah tenis lapangan, tenis meja, bulutangkis, atletik, kempo, dan cabang olahraga woodball; 2) Manajemen gizi atlet di Kabupaten Buleleng selama ini dilakukan oleh atlet sendiri dan orang tua atlet; 3) Kesesuaian manajemen gizi atlet di Kabupaten Buleleng tidak dilakukan perhitungan kebutuhan kalori terhadap atlet. Dapat disimpulkan bahwa pola asupan gizi sebagai salah satu prioritas dalam pembinaan atlet dalam pelaksanaannya belum sepenuhnya tertangani dengan baik dan manajemen gizi di Kabupaten Buleleng belum sesuai dengan perhitungan kebutuhan energi atlet bersangkutan. Dapat disarankan untuk meningkatkan prestasi olahraga di Kabupaten Buleleng sebaiknya mengaplikasikan IPTEKS Keolahragaan dan menerapkan manajemen gizi atlet yang baik.
\end{abstract}

Kata kunci : manajemen, gizi atlet, olahraga unggulan

\begin{abstract}
Sport coaching, both national and regional levels is one of annual event which is using government funds large enough. One important aspect that is often overlooked in coaching athletes are athletes nutritional factors. This study was aimed at 1) determining the existence of main sports in Buleleng regency, 2) determining the nutritional management of sports athletes featured in Buleleng
\end{abstract}


regency, 3) determining the suitability of the nutritional management of sports athletes featured in Buleleng regency. This research method was descriptive qualitative, data collected through observation, interviews and documentation. Informants were selected by purposive sampling. Data were analyzed by Interaktive Miles analysis models. The results showed that 1) Main sports in Buleleng regency are tennis, table tennis, badminton, athletics, kempo and woodball; 2) Nutritional management of athletes in Buleleng regency has been done by the athletes themselves and their parents; 3) Athlete's nutrition management in Buleleng were not based on caloric needs of the athletes. It can be concluded that the pattern of nutrient intake as a priority in coaching athletes in practice has not been fully handled properly and nutrient management in Buleleng is not in accordance with the calculation of the energy needs of the athlete concerned. It is suggested that sport science and technology and nutrition management should applied to improve athlete's performance.

Key words: management, athletes nutritional, main sports

\section{PENDAHULUAN}

Pembinaan prestasi olahraga merupakan salah satu agenda tahunan yang menggunakan dana pemerintah cukup besar baik di tingkat nasional maupun di daerah. Keberanian pemerintah mengeluarkan dana besar untuk olahraga prestasi tidak terlepas dari kebanggaan dan prestise yang bisa diperoleh dari prestasi olahraga tersebut. Besarnya dana yang dikeluarkan oleh pemerintah dalam upaya peningkatan prestasi olahraga menunjukan betapa besarnya kebutuhan masyarakat terhadap prestasi olahraga itu sendiri.

Prestasi olahraga nasional tampak stagnan bahkan cenderung menurun dalam beberapa tahun terakhir. Prestasi olahraga nasional merupakan puncak dari pembinaan prestasi olahraga di daerah. Oleh karena itu, keberhasilan pembinaan olahraga daerah merupakan kunci dari kesuksesan olahraga nasional. Salah satu kelemahan dari program pembinaan olahraga nasional saat ini adalah kurang meratanya pembangunan olahraga di daerah, terdapat perbedaan yang sangat mencolok antara pusat dan daerah baik dalam hal kemampuan teknis tenaga keolahragaan maupun sarana dan fasilitas yang tersedia.

Dalam lingkup pembinaan olahraga, berbagai ilmu mendukung tercapainya prestasi, seperti psikologi, anatomi, fisiologi, pendidikan, kesehatan olahraga, ilmu gizi dan lainnya. Secara spesifik mengenai gizi, pemberian asupan makanan yang tepat baik kualitas dan kuantitas dapat menghasilkan kondisi fisik yang optimal serta memberikan energi yang cukup bagi atlet selama menjalankan kegiatannya (Rusli L, dkk, 2000). Meskipun demikian, masih sering terjadi kesalahan dalam manajemen gizi atlet yang menjadi salah satu kelemahan pembinaan olahraga di daerah. Sangat sedikit daerah yang memiliki ahli gizi yang bisa memberikan pedoman pola makan untuk menunjang performa atlet baik sebelum pertandingan, saat pertandingan maupun setelah pertandingan. Berdasarkan penelitian yang dilakukan oleh Elizabeth, et. al. 
(2011,) ditemukan bahwa sering kali atlet tidak memperhatikan tingkat kebutuhan nutrisi yang disarankan sehingga performanya menjadi tidak optimal. Oleh sebab itu diperlukan adanya pengaturan gizi bagi atlet dan adanya pendidikan mengenai gizi bagi atlet.

Pembinaan olahraga nasional tidak bisa berdiri sendiri dan terpusat hanya di tingkat nasional. Pembinaan harus melibatkan pemerintah daerah sebagai ujung tombak pembinaan olahraga nasional. Peraturan Pemerintah RI No. 16 tahun 2007 tentang penyelenggaraan keolahragaan pasal 34 menyebutkan pembinaan dan pengembangan olahraga prestasi menjadi tanggung jawab induk organisasi cabang olahraga, organisasi cabang olahraga tingkat provinsi, dan organisasi cabang olahraga tingkat kabupaten/kota. Dalam melaksanakan tanggung jawabnya tersebut, organisasi olahraga baik pusat maupun daerah melaksanakan pemasalan, pembibitan, pembinaan dan pengembangan prestasi olahragawan, pemberdayaan perkumpulan olahraga, pengembangan sentra pembinaan olahraga, dan penyelenggaraan kompetisi secara berjenjang dan berkelanjutan. Hal ini sejalan dengan Undang-Undang Sistem Keolahragaan Nasional (UUSKN) yang telah memberi pembagian tugas dan tanggung jawab yang jelas antara pemerintah pusat dan pemerintah daerah dalam pembinaan olahraga di Indonesia.

Peran daerah telah diakui secara nasional sebagai kunci pengembangan prestasi olahraga nasional. Pengembangan cabang olahraga di daerah merupakan target dan aset terpenting untuk bisa menghasilkan atlet-atlet handal nasional. Pengembangan olahraga daerah harus didasarkan pada karakteristik daerah tersebut, dengan kata lain pengembangan olahraga di daerah harus disesuaikan dengan potensi yang ada di daerah. Pembinaan olahraga di daerah harus diawali dengan pemetaan cabang olahraga unggulan dan pengembangannya sesuai dengan cabang olahraga unggulan daerah masing-masing. Penentuan olahraga unggulan daerah dapat didasarkan pada beberapa hal diantaranya : 1) perolehan medali pada kejuaraan multi event seperti PON, Sea Games, Asian Games, dan Olimpiade, 2) minat masyarakat terhadap cabang olahraga tertentu, 3) keadaan geografis, 4) ketersediaan sarana dan prasarana, 5) kualitas kondisi fisik olahragawan, dan 6) kualitas SDM bidang olahraga (Supriadi, 2008).

Kabupaten Buleleng merupakan kabupaten dengan wilayah terluas di Bali yaitu 1.365,88 $\mathrm{Km}^{2}$ sekitar 24,5\% dari total luas wilayah Provinsi Bali. Bentang wilayah yang luas dengan tekstur dataran yang bervariasi merupakan salah satu potensi penunjang pengembangan olahraga di Kabupaten Buleleng. Menilik hasil Porprov Bali tahun 2011, cabang olahraga kempo, atletik, bulutangkis dan tenis lapangan merupakan cabang yang menyumbang medali paling banyak bagi kontingen Buleleng. Pada even Porprov terakhir tersebut, cabang kempo menyumbang 6 medali emas, atletik menjadi runner up di bawah Denpasar dengan sumbangan 5 emas. Cabang tenis lapangan menjadi juara umum dengan 4 medali emas, selain itu kontingen tenis Buleleng selalu 
menyertakan atletnya sebagai anggota kontingen Bali di ajang PON. Cabang butangkis merupakan cabang olahraga yang memiliki tradisi emas di even Porprov Bali. Pada porprov 2011 cabang bulutangkis memperoleh 3 medali emas. Prestasi yang cukup bagus pada beberapa even yang diikuti menjadikan cabang-cabang olahraga tersebut sebagai cabang olahraga unggulan Kabupaten Buleleng.

Istilah gizi berasal dari bahasa arab "giza" yang berarti zat makanan, dan dalam bahasa Inggris dikenal istilah nutrition yang berarti bahan makanan atau zat gizi. Lebih luas, gizi diartikan sebagai suatu proses organisme menggunakan makanan yang dikonsumsi secara normal melalui proses pencernaan, penyerapan, transportasi, penyimpanan, metabolismee dan pengeluaran zat gizi untuk mempertahankan kehidupan, pertumbuhan dan fungsi normal organ tubuh serta untuk menghasilkan tenaga.

Dalam lingkup pembinaan olahraga, gizi bersama-sama dengan aspek lainnya mendukung tercapainya prestasi sebab prestasi atlet ditentukan oleh kualitas latihan, sedangkan latihan yang berkualitas dapat diperoleh apabila didukung berbagai penunjang seperti status psikologi, anatomi tubuh atlet, fisiologi organ tubuh atlet, biomekanika yang terjadi dalam tubuh atlet, pendidikan dan latihan atlet, lingkungan social, status kesehatan dan status gizi atlet. Dengan adanya gizi yang baik, maka akan tersedia kecukupan energi untuk kinerja fisik yang bermanfaat untuk kesehatan, kebugaran, pertumbuhan anak serta pembinaan prestasi olahraga.
Pengetahuan akan gizi tidak hanya penting bagi seorang ahli gizi namun juga bagi masyarakat luas, termasuk atlet. Oleh karena dengan memahami hubungan nutrisi, gaya hidup, self image dan kinerja fisik, maka akan dapat membantu proses pertumbuhan anakanak, pembina, pelatih olahraga masyarakat untuk dapat membantu masyarakat mencapai derajat sehat dan bugar serta pelatih olahraga prestasi agar mampu mengoptimalkan pengembangan prestasi atletnya.

Setiap orang memerlukan jumlah makanan yang berbeda-beda, tergantung pada usia, berat badan, jenis kelamin, aktivitas fisik, kondisi lingkungan dan keadaan tertentu. Proporsi makanan sehat berimbang terdiri dari 60-65\% karbohidrat, 20\% lemak dan $15-20 \%$ protein dari total kebutuhan atau keluaran energi per hari. Namun, pembagian persentase zat gizi ini terkadang sedikit berbeda, ada pula yang menyebutkan $70 \%$ karbohidrat, $15 \%$ lemak dan $15 \%$ protein.

a. Kebutuhan karbohidrat

Orang dewasa dengan aktivitas sedang memerlukan karbohidrat rata-rata 8-12 gram $/ \mathrm{kg} \mathrm{BB} /$ hari, sedangkan kebutuhan minimal setiap orang adalah 50-100 gram/hari.

b. Kebutuhan Lemak

Untuk memelihara keseimbangan fungsinya, tubuh memerlukan lemak 0,5 hingga 1 gram $/ \mathrm{kg}$ $\mathrm{BB} /$ hari. Latihan otot meningkatkan kapasitas otot dalam menggunakan lemak sebagai sumber energi. Secara umum, konsumsi lemak dianjurkan tidak lebih dari 30\% dari total energi per hari.

c. Kebutuhan Protein 
Kebutuhan protein dapat ditentukan dengan cara menghitung jumlah nitrogen yang dikeluarkan melalui urine. Secara umum, kebutuhan protein adalah 0,8 sampai 1 gram/kg BB/hari, tetapi bagi mereka yang bekerja berat, kebutuhan protein dapat bertambah.

d. Kebutuhan Vitamin dan Mineral

Kebutuhan vitamin dan mineral akan meningkat sejalan dengan tingkat aktivitas. Atlet yang melakukan olahraga berat akan memerlukan vitamin dan mineral yang lebih banyak. Kebutuhan vitamin beraneka ragam tergantung pada fungsinya. Kecukupan vitamin dan mineral dari bahan alami sering sulit dipenuhi pada anak-anak dan atlet karena pada umumnya tidak mudah mengkonsumsi sayuran dan buah dalam jumlah besar, sehingga diperlukan suplemen vitamin dan mineral.

\section{e. Kebutuhan Air}

Untuk mempertahankan status hidrasi, stiap orang dalam seharihari rata-rata memerlukan $2500 \mathrm{ml}$ air. Jumlah tersebut setara dengan cairan yang dikeluarkan tubuh baik berupa keringat, uap air maupun yang keluar bersama tinja.

Upaya untuk memberikan makanan yang sesuai dengan kebutuhan gizi terutama olahragawan perlu diperhatikan besar aktivitas dan waktu untuk masing-masing cabang olahraga. Oleh sebab itu, untuk menentukan kebutuhan kalori olahragawan, perlu dilakukan pengelompokkan cabangcabang olahraga.

Tiap-tiap cabang olahraga memiliki dua macam latihan yang masing-masing harus dijalani oleh seorang olahragawan, yaitu latihan untuk pembinaan kondisi fisik dasar dan latihan untuk pembinaan keterampilan teknis khusus olahraga itu sendiri. Oleh sebab itu, kebutuhan akan energi (kalori) harus memperhitungkan kedua macam faktor tersebut, serta jumlah waktu (durasi) dari masing-masing latihan tersebut.

Untuk memudahkan perhitungan dalam menentukan kebutuhan energi seorang olahragawan, maka diusahakan menggolongkan macam-macam olahraga menjadi 4 kelompok, berdasarkan berat ringannya olahraga tersebut, dengan memperhitungkan kedua macam bentuk latihan (latihan kondisi fisik dan latihan keterampilan teknik) juga jumlah waktu dari masingmasing latihan yang dijalankannya. Adapun pengelompokan cabang olahraga tersebut adalah sebagai berikut:

1. Olahraga ringan: menembak, golf, bowling, panahan.

2. Olahraga sedang: atletik, bulutangkis, bola basket, hockey, softball, tenis, tenis meja, senam, sepak bola.

3. Olahraga berat: renang, balap sepeda, tinju, gulat, kempo, judo.

4. Olahraga berat sekali: balap sepeda jarak jauh (>130 km), angkat besi, marathon, rowing

Namun, pembagian berat ringannya olahraga secara resmi hingga saat ini belum ada. Apabila terdapat cabang olahraga yang belum tercantum pada daftar ini, penggolongannya supaya disesuaikan dengan cabang yang kira-kira memiliki aktivitas yang sama dengan yang ada di daftar. 
Untuk perhitungan praktis dalam menilai kebutuhan energi untuk macam- macam cabang olahraga dapat dipakai tabel di bawah ini.

Tabel 1 Kebutuhan Energi untuk Berbagai Cabang Olahraga (dalam kkal/kg. BB/24 jam)

\begin{tabular}{|c|c|c|c|c|}
\hline & $\begin{array}{c}\text { Olah } \\
\text { raga ringan }\end{array}$ & $\begin{array}{c}\text { Olah } \\
\text { raga sedang }\end{array}$ & $\begin{array}{c}\text { Olah } \\
\text { raga berat }\end{array}$ & $\begin{array}{c}\text { Olah } \\
\text { raga berat } \\
\text { sekali }\end{array}$ \\
\hline Laki-laki & 42 & 46 & 54 & 62 \\
\hline Perempuan & 36 & 40 & 47 & 55 \\
\hline
\end{tabular}

Dalam ajang Pekan Olahraga Provinsi (PORPROV) Bali tahun 2011 yang baru berakhir, berdasarkan Buleleng, banyak atlet yang mengeluhkan menu makan yang disediakan oleh kontingen. Bebagai keluhan ini terkait dengan jenis menu yang diberikan yang monoton, jumlah secara kuantitas serta tidak sesuai dengan selera atlet.

Pemberian makanan yang tepat dilihat dari segi kuantitas dan kualitas dapat menghasilkan kondisi fisik yang optimal, serta memberikan energi yang cukup bagi atlet selama menjalankan kegiatannya. Pada umumnya, atlet memerlukan makanan lebih banyak daripada yang bukan atlet, karena atlet melakukan kegiatan fisik yang jauh lebih besar. Sehingga kebutuhan energinya juga bertambah. Seorang atlet sebaiknya mengetahui berapa kebutuhan zat-zat gizi dalam sehari untuk dapat menjamin konsumsi yang mencukupi (adekuat). Selain itu, kebutuhan gizi para atlet dengan cabang olahraga yang berbeda juga harus diperhatikan mengingat tiap cabang olahraga memiliki tuntutan aktivitas fisik yang berbeda-beda. wawancara yang dilakukan dengan beberapa atlet di Kabupaten

Kondisi yang terlihat pada atlet di Kabupaten Buleleng, tentunya menjadi salah satu permasalahan yang berdampak terhadap performa atlet. Oleh karena itu penyusunan tata laksana gizi bagi atlet yang didasarkan pada kebutuhan terhadap keseimbangan energi menjadi sangat penting.

Berdasarkan latar belakang tersebut di atas, maka permasalahan dalam penelitian ini dirumuskan sebagai berikut: 1) Bagaimanakah keberadaan cabang olahraga unggulan di Kabupaten Buleleng? 2) Bagaimanakah manajemen gizi atlet cabang olahraga unggulan di Kabupaten Buleleng? 3) Bagaimanakah kesesuaian manajemen gizi atlet cabang olahraga unggulan di Kabupaten Buleleng? Tujuan penelitian ini adalah: 1) Mengetahui keberadaan cabang olahraga unggulan di Kabupaten Buleleng 2) Mengetahui manajemen gizi atlet cabang olahraga unggulan di Kabupaten Buleleng 3) Mengetahui kesesuaian manajemen gizi atlet cabang olahraga unggulan di Kabupaten Buleleng. Manfaat penelitian ini adalah: 
1) Manfaat Praktis: hasil penelitian ini dapat menjadi acuan bagi pemerintah daerah, dalam hal ini Dinas Pendidikan Pemuda dan Olahraga serta instansi olahraga terkait dalam memberikan pembinaan atlet di Kabupaten Buleleng; 2) Manfaat teoritis: hasil penelitian ini dapat menjadi referensi dalam perkuliahan IImu Gizi Olahraga di Fakultas Olahraga dan Kesehatan Undiksha. Selain itu, juga dapat menjadi referensi dalam pembinaan atlet di Bali pada khususnya dan memberikan sumbangan pemikiran terhadap khasanah ilmu tentang manajemen gizi atlet secara umum.

\section{METODE}

Rancangan penelitian ini adalah menggunakan metode penelitian deskriptif kualitatif. Penelitian ini dilaksanakan di Kabupaten Buleleng Provinsi Bali dengan mengambil populasi atlet cabang olahraga unggulan Kabupaten Buleleng. Subjek penelitian ini adalah seluruh atlet cabang olahraga unggulan Kabupaten Buleleng. adapun penentuan atlet tersebut didasarkan pada cabang olahraga yang menajdi unggulan pada tahun 2013. Berpedoman dari Neuman dalam Jenning (2001) yang menyatakan untuk jumlah populasi di bawah 1000 besarnya sampel yang diperlukan adalah $30 \%$ dari total jumlah populasi yang ada. Pengambilan sampel penelitian dilakukan dengan teknik purposif sampling. Objek penelitian ini adalah jenis cabang olahraga unggulan Kabupaten Buleleng dan tingkat kebutuhan kalori masing-masing cabang olahraga, Teknik pengumpulan data yang digunakan dalam penelitian ini adalah observasi, wawancara mendalam dan dokumentasi.

1. Observasi dilakukan untuk melakukan pengamatan langsung terhadap kondisi mnajemen gizi atlet.

2. Wawancara mendalam mencakup asupan makan selama 24 jam, dilihat dari segi kuantitas dan kualitas.

3. Dokumentasi diperlukan sebagai pedoman/panduan dalam penelitian ini. Dokumentasi juga dilakukan dengan penghitungan tingkat kebutuhan gizi masing-masing cabang olahraga sesuai dengan perhitungan kebutuhan gizi olahraga yang didasarkan pada kelompok cabang olahraga, jenis kelamin dan berat badan atlet.

Teknik analisis data menggunakan Analisis Interaktive model dari Miles dan Huberman terdiri dari empat tahap yaitu pengumpulan data, reduksi data, penyajian data dan penarikan simpulan/verifikasi.

\section{HASIL}

\section{Keberadaan cabang olahraga unggulan di Kabupaten Buleleng \\ Berbagai cabang olahraga} berkembang dengan cukup pesat dan digemari oleh masyarakat di Kabupaten Buleleng, antara lain cabang olahraga sepakbola, tenis lapangan, bulutangkis, tenis meja, sepak takraw dan berbagai cabang olahraga lainnya. Berdasarkan data yang terdapat di KONI Buleleng, hasil PORPROV tahun 2013 prestasi kabupaten Buleleng berada diposisi ke 4 klasemen akhir di bawah kontingen Kabupaten Badung, kontingen Kodya Denpasar, dan Kontingen Kabupaten 
Gianyar dengan rincian perolehan medali: 30 medali emas, 64 medali perak, dan 79 medali perunggu. Berdasarkan hasil PORPROV tahun 2011 perolehan medali kontingen Kabupaten Buleleng adalah sebagai berikut : medali emas 34 buah, medali perak 47 buah dan medali perunggu 65 buah. Dari berbagai cabang olahraga tersebut, terdapat beberapa cabang yang menjadi olahraga unggulan di Kabupaten Buleleng. Berdasarkan wawancara kepada Ketua KONI dan pengumpulan data dokumentasi, cabang olahraga yang menjadi unggulan Kabupaten Buleleng adalah cabang tenis lapangan, tenis meja, bulutangkis, atletik, kempo, dan cabang olahraga woodball.

Di lain pihak, di Buleleng terdapat Universitas Pendidikan Ganesha yang memiliki Fakultas Olahraga dan Kesehatan. Kelebihan tersebut merupakan potensi yang sangat baik untuk mengembangkan dan memajukan prestasi olahraga di Kabupaten Buleleng. Karena kolaborasi yang baik antara IPTEK bidang Keolahragaan yang dimiliki oleh FOK Undiksha akan sangat membantu pembinaan atlet Kabupaten Buleleng. Di seluruh dunia saat ini penelitianpenelitian di bidang keolahragaan telah diakui sangat membantu dalam pencapaian prestasi yang optimal bagi atlet.

\section{Manajemen gizi atlet cabang olahraga unggulan di Kabupaten Buleleng}

Perhatian terhadap tingkat kebutuhan nutrisi atlet merupakan salah satu faktor agar performa menjadi optimal. Oleh sebab itu diperlukan adanya pengaturan gizi bagi atlet dan adanya pendidikan mengenai gizi bagi atlet. Manajemen gizi bagi atlet merupakan hal yang penting. Berdasarkan wawancara mendalam kepada pelatih cabang olahraga unggulan Buleleng yaitu kempo, bulutangkis, tenis lapangan dan atletik, didapatkan bahwa pengaturan gizi atlet merupakan salah satu prioritas dalam proses pelatihan. "Pengaturan makan atlet bersama dengan latihan merupakan prioritas dalam pembinaan." Selain itu, semua pelatih mengatakan bahwa manajemen gizi merupakan penentu performa atlet. "Perhatian terhadap asupan makanan atlet mendapatkan prioritas pertama, karena makanan sangat besar pengaruhnya terhadap kesehatan dan kebugaran atlet untuk meningkatkan prestasi." Asupan makanan yang memadai bagi seorang atlet akan memberikan dampak baik bagi latihan yang dapat dilakukannya. Hal tersebut akan semakin menunjang pencapaian prestasi.

Penyedia makanan merupakan aspek penting dalam pengaturan gizi seorang atlet. Berdasarkan wawancara kepada pelatih dan atlet, sebagian besar mengatakan bahwa penyediaan makanan selama ini dilakukan oleh atlet sendiri (orang tua atlet). "Selama ini makanan saya disediakan oleh orang tua di rumah." "Makanan disediakan oleh atlet masing-masing, yaitu orang tua." "Orang tua yang menyediakan makanan saya sehari-hari." Bahkan beberapa atlet menyebutkan bahwa dirinya sendiri yang mengatur pola makannya karena selama ini tinggal terpisah dengan orang tua (kost/mengontrak). Beberapa pelatih menyebutkan bahwa masing-masing 
cabang olahraga memiliki pengaturan tersendiri dalam hal asupan makanan. Disebutkan bahwa pada beberapa cabang olahraga terdapat bantuan yang diberikan bagi atlet,yaitu dalam bentuk suplemen vitamin. "Untuk makanan atlet sehari-hari diatur oleh atlet sendiri, kami dari pelatih hanya menambah suplemen/multivitamin." Pada saat atlet menjalani pembinaan khusus (training centre) untuk persiapan jangka pendek pertandingan yang akan dihadapi, beberapa pelatih dan atlet menyebutkan bahwa bantuan dalam hal gizi bagi atlet diberikan saat atlet menjalani training centre (TC).

Pola pengaturan makan atlet selama 24 jam disebutkan berdasarkan wawancara kepada atlet adalah 3 kali sehari, yaitu pagi (sarapan), makan siang dan makan malam. "Dalam sehari saya makan 3 kali, pagi, siang dan malam." "Makan 3 kali sehari, pagi pk. 07.00, siang pk. 13.00 dan malam pk. 19.00, kadang-kadang ada camilan kue, kadang enggak." Tiap kali makan (pagi/siang/malam) dikatakan satu piring yang berisi nasi, lauk, dan sayur tanpa disertai perhitungan komposisinya. "Saya tidak pernah menghitung (memperhitungkan) komposisi makanan, hanya sesuai keinginan saja."

Berdasarkan pola asupan makanan atlet, pendapat para atlet mengenai kecukupan kebutuhan asupan makanan berbeda-beda. Sebagian mengatakan sudah mencukupi, sebagian lagi mengatakan belum mencukupi kebutuhan. "Makanan yang disediakan orang tua sudah mencukupi kebutuhan saya, makanannya enak dan bergizi." " Makanan yang saya makan sudah memenuhi syarat 4 sehat." Makanan yang disediakan saya rasakan sudah mencukupi kesehatan bagi tubuh meskipun tanpa asupan 4 sehat 5 sempurna." Adapun beberapa pendapat atlet yang menyebutkan asupan makanan belum mencukupi antara lain "Makanan yang saya konsumsi selama ini saya rasa belum mencukupi kebutuhan, karena menunya tidak pernah lengkap." "Makanan yang disediakan kurang mencukupi kebutuhan tubuh saya, makanannya kurang beragam."

Pelatih dan atlet cabang olahraga unggulan di Kabupaten Buleleng mengutarakan perlunya perbaikan terhadap manajeman gizi atlet. Perhatian yang lebih tinggi terhadap pola asupan makanan atlet sejak pembinaan awal, persiapan pertandingan hingga pertandingan. Peningkatan keberagaman makanan agar tercapai 4 sehat 5 sempurna, termasuk suplemen makanan (vitamin). Penggunaan ahli gizi sebagai pihak yang daapt memberikan pengaturan manajemen gizi atlet agar sesaui dengan kebutuhan. Hingga adanya pendidikan bagi pelatih dan atlet mengenai manajamen gizi.

\section{Kesesuaian manajemen gizi atlet cabang olahraga unggulan di Kabupaten Buleleng}

Perhitungan dalam menentukan kebutuhan energi seorang olahragawan disesuaikan dengan kelompok berat ringannya cabang olahraga yang digeluti (olahraga ringan, sedang, berat dan berat sekali). Berdasarkan perhitungan kebutuhan kalori, kebutuhan masingmasing cabang olahraga unggulan Buleleng adalah sebagai berikut:

a. Bulutangkis 
1) Laki-laki $=46 \mathrm{kkal} / \mathrm{kg} \cdot \mathrm{BB} / 24$ jam

2) Perempuan $=40 \mathrm{kkal} / \mathrm{kg} \cdot \mathrm{BB} / 24$ jam

b. Atletik

1) Laki-laki $=46 \mathrm{kkal} / \mathrm{kg} \cdot \mathrm{BB} / 24$ jam

2) Perempuan $=40 \mathrm{kkal} / \mathrm{kg} . \mathrm{BB} / 24$ jam

c. Tenis lapangan

1) Laki-laki $=46 \mathrm{kkal} / \mathrm{kg}$. BB/24 jam

2) Perempuan $=40 \mathrm{kkal} / \mathrm{kg}$. BB/24 jam

d. Kempo

1) Laki-laki $=54 \mathrm{kkal} / \mathrm{kg} \cdot \mathrm{BB} / 24$ jam

2) Perempuan $=47 \mathrm{kkal} / \mathrm{kg} \cdot \mathrm{BB} / 24$ jam

Dengan mengetahui besar total kalori yang diperlukan, dapat dihitung besar kalori yang bersumber dari karbohidrat, protein dan lemak. Karbohidrat sebesar $60 \%$, protein sebesar $20 \%$ dan lemak sebesar $20 \%$. Selanjutnya dihitung jumlah masingmasing makronutrient dalam gram. Karbohidrat sebesar 4 kalori/gram, protein sebesar 4 kalori/gram dan lemak sebesar 9 kalori/gram.

Berdasarkan wawancara dan observasi, ditemukan bahwa selama ini tidak dilakukan perhitungan kebutuhan kalori terhadap atlet. Atlet menyebutkan bahwa pola makan mereka pada umumnya tiga kali sehari, terkdang ditambah dengan snack dan suplemen/vitamin. "Dalam satu hari atlet makan 3 kali sehari, tiap kali makan 1 porsi (satu piring). Tidak ditentukan seberapa banyak isi dalam satu porsi makan." Jumlah asupan makanan yang diberikan hanya berdasarkan perkiraan bahkan sering kali disesuaikan dengan keinginan atlet. Beberapa atlet menyampaikan bahwa jadwal makan mereka selama ini tidak teratur.

\section{PEMBAHASAN}

Prestasi sebuah cabang olahraga didukung oleh berbagai aspek. Berawal dari pembinaan yang dilakukan oleh daerah hingga ke pusat. Tanpa adanya pembinaan yang baik di daerah, maka tidak akan dapat diperoleh hasil yang maksimal. Dalam melaksanakan tanggung jawab penyelenggaraan olahraga, organisasi olahraga baik pusat maupun daerah melaksanakan pemasalan, pembibitan, pembinaan dan pengembangan prestasi olahragawan, pemberdayaan perkumpulan olahraga, pengembangan sentra pembinaan olahraga, dan penyelenggaraan kompetisi secara berjenjang dan berkelanjutan. Pembinaan di daerah sangat berperan sebagai kunci pengembangan prestasi olahraga nasional.

Pembinaan olahraga di daerah harus diawali dengan pemetaan cabang olahraga unggulan dan pengembangannya sesuai dengan cabang olahraga unggulan daerah masing-masing. Berdasarkan hasil penelitian, cabang olahraga yang menjadi unggulan Kabupaten Buleleng adalah tenis lapangan, tenis meja, bulutangkis, atletik, kempo, dan cabang olahraga woodball. Pemetaan cabang olahraga unggulan di Kabupaten

Buleleng tersebut didasarkan pada perolehan medali pada kejuaraan multi event, yaitu PORPROV tahun 2013.

Keberhasilan atlet untuk mendapatkan prestasi ditentukan oleh berbagai hal. Berbagai aspek mendukung 
keberhasilan tersebut, antara lain psikologi, anatomi, fisiologi, pendidikan, kesehatan olahraga, ilmu gizi dan lainnya. Berdasarkan hasil penelitian didapatkan bahwa manajemen gizi seorang atlet merupakan hal penting, bahkan mendapatkan prioritas utama dalam pembinaan atlet di kabupaten Buleleng. hasil tersebut sesuai dengan teori yang menyebutkan bahwa pemberian asupan makanan yang tepat baik kualitas dan kuantitas dapat menghasilkan kondisi fisik yang optimal serta memberikan energi yang cukup bagi atlet selama menjalankan kegiatannya (Rusli L, dkk, 2000). Manajemen gizi seorang atlet, baik sebelum pertandingan, saat pertandingan maupun setelah pertandingan akan berdampak besar terhadap performa yang ditampilkan.

Hasil penelitian menunjukkan bahwa baik atlet maupun pelatih menempatkan pola asupan gizi sebagai salah satu prioritas dalam pembinaan atlet. Hal ini sejalan dengan teori bahwa nutrisi yang optimal penting bagi performa terbaik atlet. (Gaspar, 2010). Meskipun menjadi salah satu prioritas, namun dalam pelaksanaannya manajemen gizi atlet belum sepenuhnya tertangani dengan baik. Sebagian besar responden mengatakan bahwa penyediaan makanan selama ini dilakukan oleh atlet sendiri (orang tua atlet). Masing-masing cabang olahraga memiliki pengaturan tersendiri dalam hal asupan makanan. Namun, pada beberapa cabang olahraga terdapat bantuan yang diberikan bagi atlet, yaitu dalam bentuk suplemen vitamin. Penambahan suplemen ini dirasakan cukup membantu bagi atlet.
Berdasarkan hasil penelitian, pola pengaturan makan atlet selama 24 jam mencakup makan pagi, siang dan malam. Tiap kali makan (pagi/siang/malam) dikatakan satu piring yang berisi nasi, lauk dan sayur tanpa disertai perhitungan komposisinya. Hal tersebut perlu mendapatkan perbaikan. Pemilihan nutrisi yang baik bagi seorang atlet yang disesuaikan dengan kebutuhan masing-masing (usia, jenis kelamin, cabang olahraga dan level kompetisi) nantinya akan dapat memberikan banyak keuntungan terkait dengan performa atlet. (IAAF Athletic, 2011)

Secara spesifik keuntungan yang akan diperoleh dengan manajemen gizi yang baik adalah hasil pembinaan yang optimal, perbaikan kondisi atlet yang meningkat, berat badan dan fisik yang idel, menurunnya resiko kecelakaan dan kesakitan, tingkat percaya diri yang meningkat dan performa yang stabil. (IAAF Athletic, 2011) Adapun kerugian yang akan terjadi bila manajemen gizi atlet tidak baik selain tidak adanya keuntungan-keuntungan di atas adalah meningkatnya biaya pemeliharaan kesehatan, pemilihan makanan yang buruk (tidak sesuai kebutuhan tubuh). Pemilihan makanan dan minuman dengan availabilitas yang buruk dan penggunaan suplemen makanan yang tidak tepat.

Kecukupan kebutuhan nutrisi berdasarkan hasil penelitian ditemukan bahwa belum tercukupi sepenuhnya. Seringkali dalam porsi makan atlet tidak mencakup kebutuhan nutrient yang sesuai kebutuhan. Proporsi makanan sehat berimbang terdiri dari $60-65 \%$ karbohidrat, 20\% lemak dan 15-20\% protein dari total kebutuhan atau 
keluaran energi per hari. (Djoko, 2006) Persentase nutrisi atlet cabang olahraga unggulan kabupaten Buleleng belum memenuhi porsi makanan sehat seimbang tersebut. Terkait dengan kebutuhan kalori perhari, berdasarkan hasil penelitian ditemukan bahwa selama ini tidak ada perhitungan kebutuhan energi bagi atlet. Pemenuhan nutrisi hanya didasarkan pada perkiraan masing-masing atlet, tidak dilakukan penakaran. Kondisi demikan akan berdampak buruk bagi atlet. Seperti yang disebutkan dalam IAAF Athletic (2011), asupan makanan memiliki pengaruh yang terhadap latihan dan nutrisi yang baik akan mendukung latihan yang intensif serta mencegah resiko cedera. Pemilihan asupan yang baik juga akan membantu dalam adaptasi terhadap stimulus latihan. Pemenuhan kebutuhan kalori yang tepat akan menempatkan atlet dalam kondisi sehat dan performa yang optimal. Kelebihan asupan kalori akan berdampak pada peningkatan lemak tubuh, sedangkan kekurangan asupan kalori berdampak pada menurunnya performa dan peningkatan resiko cedera.

\section{SIMPULAN}

Berdasarkan hasil penelitian dan pembahasan, maka dapat ditarik simpulan sebagai berikut: 1) Cabang olahraga unggulan kabupaten Buleleng adalah tenis lapangan, bulutangkis, atletik dan kempo. 2) Pola asupan gizi sebagai salah satu prioritas dalam pembinaan atlet, namun dalam pelaksanaannya manajemen gizi atlet belum sepenuhnya tertangani dengan baik. 3) Manajemen gizi atlet cabang olahraga unggulan di kabupaten Buleleng belum sesuai dengan perhitungan kebutuhan energi atlet bersangkutan. Dapat disarankan: untuk meningkatkan prestasi olahraga di Kabupaten Buleleng sebaiknya mengaplikasikan IPTEKS Keolahragaan dengan bekerjasama dengan FOK Undiksha dan menerapkan manajemen gizi atlet yang baik.

\section{UCAPAN TERIMA KASIH}

Terimakasih yang sebesarbesarnya penulis sampaikan kepada Lembaga Penelitian Undiksha yang telah memberikan kesempatan kepada peneliti untuk melakukan penelitian ini. Kepada pihak KONI Kabupaten Buleleng peneliti juga menyampaikan ucapan terimakasih atas kerjasamanya sehingga penelitian ini dapat terlaksana.

\section{DAFTAR PUSTAKA}

Anwari Irawan, 2007. Nutrisi, Energy dan Performa Olahraga, Polton Sport Science \& Performance Lab. (Online), (http:// www.pssplab.com, diakses 1 September 2012)

Ayu Widiastuti Putu, Wara Kushartanti, Kandarina Istiti, 2009. Pola Makan dan Kebugaran Jasmani atlet Pencak Silat selama Pelatihan Daerah Pekan Olahraga Nasional XVII Propinsi Bali tahun 2008. Jurnal Gizi Klinik Indonesia Vol. 6, No. 1, Juli 2009:13-20.

Berardi, et al. 2008. Recovery from a cycling time trial is enhanced with carbohydrate-protein supplementation vs. isoenergetic 
carbohydrate supplementation. Journal of the International Society of Sports Nutrition; 5:24. (http://www.jissn.com/)

Bridget K., Louise A. Baur, Adrian E. Bauman, Lesley K., Kathy C. Ben J., Smith. 2010. Food and Drink Sponsorship of Children's Sport in Australia: Who Pays? Health Promotion International; 26: 1-8.

Djoko Pekik Irianto, 2006. Panduan Gizi Lengkap Keluarga dan Olahragawan. Penerbit Andi. Yogyakarta.

Elizabeth, et al. 2011. Perceived protein needs and measured protein intake in collegiate male athletes: an observational study. Journal of the International Society of Sports Nutrition; 8:9. (http://www.jissn.com/)

Ellie Whitney, Sharon Rady Rolfes, 2007. Understanding Nutrition. Thomson Corporation. United States of America.

Gaspar, Eric J., 2010. Nutrition Guide for College Aged Athlete. Departement of Kinesiology, Saint Mary's College of California.

Hadisasmita, Yusuf dan Aif Syarifuddin. 1996. IImu Kepelatihan Dasar. Jakarta: Depdiknas Dikti LPTK.

IAAF Athletic. 2011. Nutrition for Athletic. IAAF International Consensus and Conference.

Johannes H. G. M., Van Beek, Farahaniza S., Anand K., Albert
A., De Graaf., Thomas W., Hannes H. 2011. Simulating The Physiology Of Athletes During Endurance Sports Events: Modelling Human Energy Conversion and Metabolism. Philosophical Transaction; 369: 4295-4315.

Masri Singarimbun dan Sofian Effendi. 1995. Metode Penelitian Survai. Jakarta: PT Pustaka LP3ES Indonesia.

Nancy Clark, 1996. Petunjuk Gizi untuk Setiap Cabang Olahraga. PT Rajagravindo Persada. Jakarta.

Nazir, Mohhamad. 2005. Metode Penelitian. Bogor: Ghalia Indonesia.

Peraturan Pemerintah Republik Indonesia Nomor 16 tahun 2007 tentang Penyelenggaraan Keolahragaan.

Petróczi, 2011. Performance enhancement with supplements: incongruence between rationale and practice. Journal of the International Society of Sports Nutrition 2007, 4:19. (http://www.jissn.com/)

Rusli Lutan, Cecep Habibudin, Adang Suherman. 2000. Gizi Olahraga. Departemen Pendidikan dan Kebudayaaan. Jakarta.

Sajoto, 1995. Peningkatan dan Pembinaan Kekuatan Kondisi Fisik dalam Olahraga. Jakarta: Dahara Prize. 